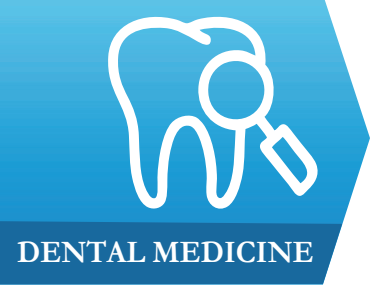

1) Kalinga Institute of Dental Sciences, KIIT Deemed to be University, Campus 5, Patia, Bhubaneswar, Odisha, India

2) Department of Public Health Dentistry, Rajasthan Dental College \& Hospital, Jaipur, Rajasthan, India

3) Department of Oral Surgery, Kalinga Institute of Dental Sciences, KIIT Deemed to be University, Campus 5 , Patia, Bhubaneswar, Odisha, India

4) Department of Public Health Dentistry, Institute of Dental education and Advance Studies, Gwalior, MP, India

\section{The Birhor tribes of Ramgarh District, Jharkhand - a ferret into their oral health status and treatment needs}

\author{
Gunjan Kumar' ${ }^{1}$, C L Dileep ${ }^{2}$, Alok Kumar Sethi ${ }^{3}$, Bhaskar Gupta ${ }^{4}$
}

\begin{abstract}
Aim and objectives. Jharkhand is a land of 32 listed Tribes, out of which eight tribes have been categorized as 'Primitive Tribes' and the Birhors are one among these. The study was aimed at assessing the oral health status and treatment needs of the native Birhors.

Material and methods. A cross-sectional household survey of 400 Birhors in the panchayats of Basantpur, Kuju Purvi and Mandu Chatti was conducted. A modified World Health Organization (WHO) Oral Health Assessment Form (1997) was utilized and examined according to the WHO methodology (1997). The recorded data were statistically analyzed using the SPSS version 15 .

Results. Based on the occupation, it was found that 141 (35.25\%) subjects were hunters and $90(22.50 \%)$ subjects practiced agriculture. A majority of $337(84.25 \%)$ subjects were using the Sakhua twigs (Shorea robusta) to clean their teeth. It was observed that $381(95.25 \%)$ subjects were quite healthy and had no oral mucosal lesions. Almost half of the study subjects $(45 \%)$ were habituated to tobacco and among them 101 (56.11\%) subjects were using khaini, followed by $46(25.56 \%)$ subjects who used bidis. The mean decayed, missing, and filled teeth (DMFT) Index scores among males and females was $1.05 \pm 2.59$ and $1.02 \pm 2.17$, respectively. Subjects with bleeding gums were predominantly seen in the age group of 2-5 years $(26.75 \%)$ and those with shallow pockets were more commonly seen in the age group of $16-34$ years $(47.12 \%)$. A total of $53(13.25 \%)$ subjects and $33(8.25 \%)$ subjects had a LOA of 4-5 mm and 6-8 mm, respectively. Among males, $0.44 \pm 2.60$ subjects each needed one/two surface fillings. A total of $14(3.5 \%)$ and $15(3.75 \%)$ subjects needed one-unit prosthesis in the upper and lower jaws, respectively.
\end{abstract}

Conclusion. The study showed that a majority of Birhor tribals (84.25\%) used Sakhua twigs to clean their teeth. Almost half of the study subjects (45\%) were habituated to tobacco in myriad forms.

Keywords: oral health, treatment needs, Birhors, tribal people

\section{Introduction}

The Government of India, recognizes 635 groups as Scheduled Tribes (ST) and 75 primitive communities who have been designated as 'particularly vulnerable tribal groups' (PVTG) based on their pre-agricultural level of technology, low level of literacy, stagnant or diminishing population size, relative seclusion or isolation from the main stream of the population, economical and educational backwardness, extreme poverty, dwelling in remote inaccessible hilly terrains, maintenance of constant touch with the natural environment, and unaffected by the developmental process undergoing in the country [1,2]. Jharkhand, the 28th State of India was carved out of the southern part of the State of Bihar on 15th November 2000. Jharkhand contributes $8.3 \%$ of tribal population to the total ST population of India. According to the 2011 decadal census, $26.2 \%$ population of Jharkhand comprises ST category. Jharkhand is a land of 32 listed Tribes, out of which 
eight tribes have been categorized as 'Primitive Tribes' (Asur, Birjia, Birhor, Kharwar, Parhaiya (Baiga), Saber, Malpahariya \& Sauria Pahariya). The Birhors are one among these primitive tribes [3] and the name is derived from the word 'Bir', meaning jungle and 'Hor' meaning people and thus denoting the 'people of the jungle'. The Birhors of Jharkhand belongs to the Porto-Australoid stock. They lead a hunter-gatherer life and their mother tongue Birhor is an Astro-Asiatic language [4]. As per the 2011 census the total population of Birhors in India is 17,241, out of which about $62 \%$ are settled in Jharkhand. However, the figure is doubtful as their population in Jharkhand is not more than 7,514 [5].

The tribal population all over India have remained eugenically and culturally disaffected from the mainstream Indian society until beneficial and supervision activities in tribal areas forced synergy between them. Even though major developments with regard to tribal welfare have gradually led to appreciable improvements in the general health status of these tribes, the case of oral health remains far neglected especially among the underprivileged tribal populations [6]. Numerous studies have been conducted on the health status of different primitive tribal communities in India but very few studies have been reported on the tribal populace of Jharkhand, especially with regard to oral health and reliable data is quite scarce. Oral health is a decisive and vital component of overall health and is not just limited to healthy teeth. Hence, the present study was undertaken with the objective of assessing the oral health status and treatment requirements as also the oral hygiene practices among the native Birhor tribes.

\section{Material and methods}

\section{Study population}

The study population consisted of tribals of 'Birhor' origin in the Mandu Block of Ramgarh District, Jharkhand. The study was carried out in the villages of Daru Kasmar (Basantpur Panchayat), Murpa (Kuju Purvi Panchayat) and Baladohar, Dandudohar \& Govindpuri (Mandu Chatti Panchayat) on 400 Birhors tribals.

\section{Study Design}

A cross-sectional household survey of Birhors in the villages of Daru Kasmar, Murpa, Baladohar, Dandudohar and Govindpuri was conducted in the months of January and February 2016.

\section{Sampling Design}

A multi-stage random sampling procedure was used for the sample selection. One out of 6 Blocks in Ramgarh District was randomly selected (Mandu Block with 41 Panchayats). Further, three out of 41 Panchayats (Basantpur, Kuju Purvi and Mandu Chatti Panchayats) were randomly selected. Furthermore, five villages were randomly selected from these Panchayats. The sample size was calculated using the formula: $\mathrm{n}=\mathrm{z} 2 \mathrm{pq} / \mathrm{d} 2$, where $\mathrm{n}$ is the sample size, $\mathrm{p}$ the prevalence of disease, $\mathrm{q}$ those free from disease, $\mathrm{d}$ the allowable error and $\mathrm{z}$ a point on the normal deviation [7]. Upon calculating, the $\mathrm{n}$ required was found to be 370 and in order to cover for the nonrespondents a total of 400 subjects were examined during the study.

Official Permission and Ethical Clearance

The ethical clearance was obtained from the Institutional Review Board. The permission to conduct the study was obtained from the Office of the Civil Surgeon, Department of Health, Medical Education \& Family Welfare, Ramgarh, Government of Jharkhand.

\section{Informed consent}

A written informed consent was obtained from all the subjects who were willing to participate in the study.

\section{Survey Proforma}

A modified World Health Organization (WHO) Oral Health Assessment Form (1997) was utilized to record the information related to oral health. In this proforma, oral hygiene practices, dietary habits and the deleterious habits of alcohol consumption and tobacco chewing were also recorded.

\section{Training and Calibration}

A single examiner was trained and calibrated in the Department of Public Health Dentistry, Kalinga Institute of Dental Sciences, Bhubaneswar, Odisha, to prevent any diagnostic variability among the study participants. The investigator himself conducted all the clinical examinations with the help of recording assistants.

\section{Data Collection}

The oral health examination of subjects was conducted according to the WHO methodology, using the Community Periodontal Index (CPI) probe and a plane mouth mirror. A Type III clinical examination was carried out under adequate natural light [8]. All the subjects who were present on the day of examination were included in the study.

\section{Statistical Analysis}

The recorded data were compiled and entered into a spreadsheet computer program (Microsoft Excel 2007) and analyzed using the SPSS version 15. The descriptive statistics included computation of percentages, means and standard deviation. The statistical tests applied for the analysis were, Chi-square test, student's t-test and one way analysis of variance. For all the statistical tests, the Confidence Level and the Level of Significance were set at $95 \%$ and $5 \%$, respectively. 


\section{Results}

A total of 400 subjects were examined in the study. Among them, 177 were males and 223 were females with age ranging from 2-74 years. Based on the occupation, it was seen that $141(35.25 \%)$ subjects were hunters and 95 $(23.25 \%)$ subjects toiled as laborers to eke out a living. A total of $337(84.25 \%)$ and $35(8.75 \%)$ subjects were using the Sakhua twigs (Shala or Sal tree - Shorea robusta) and the toothbrush to clean their teeth, respectively (Table I). When examined for oral mucosal lesions it was found that $381(95.25 \%)$ subjects were quite healthy and had no abnormal conditions. Only $12(3.00 \%)$ subjects had leukoplakia and 2 subjects $(0.50 \%)$ each suffered from ulceration and other conditions. A total of $103(27.03 \%)$ subjects were healthy in the 16-34 year age group. Leukoplakia was seen among 12 (3.0\%) subjects in the 1644 year age group.

Table I. Characteristics of the study group.

\begin{tabular}{l|l|l}
\hline Particulars & Total number (n) & Percentage (\%) \\
\hline Age Group & & \\
2-5 years & 45 & 11.25 \\
6-12 years & 59 & 14.75 \\
13-15 years & 27 & 6.75 \\
16-34 years & 109 & 27.25 \\
35-44 years & 61 & 15.25 \\
45-64 years & 72 & 18.00 \\
65-74 years & 27 & 6.75 \\
Gender & & \\
Male & 177 & 44.25 \\
Female & 223 & 55.75 \\
Occupation & & \\
Hunter & 141 & 35.25 \\
Agriculture & 90 & 22.50 \\
Rope maker & 74 & 18.50 \\
Laborer & 95 & 23.75 \\
Oral hygiene Practices & & \\
Twig & 337 & 84.25 \\
Tooth brush & 35 & 8.75 \\
Finger & 28 & 7.00 \\
Total & 400 & 100 \\
& &
\end{tabular}

A total of $180(45 \%)$ subjects were addicted to tobacco usage and used the locally available commercial tobacco products. A total of $101(56.11 \%)$ subjects used tobacco in the form of Khaini (a preparation made from tobacco leaves, mixed with slaked lime) followed by bidi smoking among 46 (25.56\%) subjects. Gutkha (tobaccolaced areca nut pieces) chewing was predominantly seen in the 16-34 year age group among 14 (42.43\%) subjects and the bolus was usually placed under the tongue or in the vestibule for extended periods (Table II).
Table II. Deleterious tobacco related habits in the study group.

\begin{tabular}{|c|c|c|c|c|}
\hline \multirow{2}{*}{$\begin{array}{l}\text { Age group } \\
\text { (in years) }\end{array}$} & \multicolumn{3}{|c|}{ Material } & \multirow{2}{*}{$\begin{array}{c}\text { Total } \\
\text { No. }(\%)\end{array}$} \\
\hline & $\begin{array}{l}\text { Gutkha } \\
\text { No. (\%) }\end{array}$ & $\begin{array}{l}\text { Khaini } \\
\text { No. }(\%)\end{array}$ & $\begin{array}{c}\text { Bidi } \\
\text { No. }(\%)\end{array}$ & \\
\hline $2-5$ & $0(0)$ & $0(0)$ & $0(0)$ & $0(0)$ \\
\hline $6-12$ & $0(0)$ & $0(0)$ & $0(0)$ & $0(0)$ \\
\hline $13-15$ & $2(6.06)$ & $4(3.96)$ & 0 & $6(3.33)$ \\
\hline $16-34$ & $14(42.43)$ & 35 (34.66) & $12(26.09)$ & $61(33.89)$ \\
\hline $35-44$ & $6(18.18)$ & $24(23.76)$ & $17(36.96)$ & $47(26.11)$ \\
\hline $45-64$ & $11(33.33)$ & $28(27.72)$ & $14(30.43)$ & $53(29.45)$ \\
\hline $65-74$ & $0(0)$ & $10(9.90)$ & $3(6.52)$ & $13(7.22)$ \\
\hline Total & 33 (18.33) & $101(56.11)$ & $46(25.56)$ & $180(100)$ \\
\hline
\end{tabular}

Among males the mean number of sextants with bleeding and calculus was $2.54 \pm 2.33$ and $0.88 \pm 1.59$ and among females they were $2.72 \pm 2.29$ and $1.20 \pm 2.28$, respectively. The presence of mean shallow and deep pockets for the group was $0.62 \pm 0.93$ and $0.15 \pm 0.43$, respectively. Subjects with bleeding gums were predominantly seen in the age group of $13-15$ years $(3.44 \pm 2.77)$ and subjects with shallow pockets were more commonly seen in the age group of 65-74 years (1.14 \pm 0.90$)$. Statistically significant differences were observed across the age groups $(p<0.05)$ (Table III).

Table III. Age-wise distribution of Community Periodontal Index (CPI) scores

\begin{tabular}{c|c|c|c|c|c}
$\begin{array}{c}\text { Age } \\
\text { Group }\end{array}$ & $\begin{array}{c}\text { Healthy } \\
\text { Mean (sd) }\end{array}$ & $\begin{array}{c}\text { Bleeding } \\
\text { Mean (sd) }\end{array}$ & $\begin{array}{c}\text { Calculus } \\
\text { Mean (sd) }\end{array}$ & $\begin{array}{c}\text { Pocket } \\
\mathbf{4 - 5} \mathbf{~ m m} \\
\text { Mean (sd) }\end{array}$ & $\begin{array}{c}\text { Pockets } \\
\mathbf{6} \text { (smm } \\
\text { Mean (sd) }\end{array}$ \\
\hline $6-12$ & $4.71 \pm 2.56$ & $1.29 \pm 2.56$ & $.00 \pm .00$ & $.00 \pm .00$ & $.00 \pm .00$ \\
$13-15$ & $3.93 \pm 2.83$ & $3.44 \pm 2.77$ & $.27 \pm 1.13$ & $.00 \pm .00$ & $.00 \pm .00$ \\
$16-34$ & $0.45 \pm 1.57$ & $3.33 \pm 2.05$ & $1.22 \pm 1.67$ & $.86 \pm 1.04$ & $0.14 \pm 0.34$ \\
$35-44$ & $0.51 \pm 1.62$ & $2.62 \pm 1.63$ & $1.4 \pm 1.71$ & $1.08 \pm 1.01$ & $0.36 \pm 0.58$ \\
$45-64$ & $1.10 \pm 2.12$ & $2.37 \pm 1.72$ & $1.24 \pm 1.49$ & $0.92 \pm 0.91$ & $0.37 \pm 0.61$ \\
$65-74$ & $0.86 \pm 2.27$ & $1.71 \pm 2.36$ & $2.29 \pm 2.14$ & $1.14 \pm 0.90$ & $.00 \pm .00$ \\
Total Mean & $1.51 \pm 2.56$ & $2.65 \pm 2.31$ & $1.07 \pm 1.68$ & $0.62 \pm 0.93$ & $0.15 \pm 0.43$ \\
F-Value & 0.017 & 0.007 & 0.043 & 0.002 & 0.034 \\
P-Value & $0.006 * * *$ & $0.410 *$ & $0.032 * *$ & $0.002 * *$ & $0.023 * *$ \\
*NS=Not Significant, **S=Significant, ***HS=Highly Significant
\end{tabular}

When the study group was examined for the periodontal loss of attachment (LOA), it was found that $298(74.5 \%)$ subjects had a LOA $0-3 \mathrm{~mm}$. A total of 33 $(8.25 \%)$ subjects and $16(4.0 \%)$ subjects had a LOA of 6-8 $\mathrm{mm}$ and $9-11 \mathrm{~mm}$, respectively (Table IV).

The mean decayed, missing, and filled teeth (DMFT) scores among males and females was $1.05 \pm 2.59$ and $1.02 \pm 2.17$ teeth, respectively, and the findings were not statistically significant $(\mathrm{p}>0.05)$ (Table V).

The mean decayed, missing, and filled teeth (dmft) scores was $1.12 \pm 2.27$ in subjects $2-5$ years old and in the higher age groups of 35-44 years and 65-74 years, the scores were $0.72 \pm 1.45$ and $1.69 \pm 4.76$ teeth, respectively. However, the results were not statistically significant $(\mathrm{p}>0.05)$ (Table VI). 
Among males, the mean number of teeth requiring one and two surface fillings was $0.44 \pm 2.60$ each and extraction was required for $0.38 \pm 2.80$ teeth. Among females they were $0.19 \pm 0.50,0.25 \pm 0.60$ and $0.18 \pm 0.68$ teeth, respectively. However, the findings were not statistically significant $(\mathrm{p}>0.05)$. Table VII shows the distribution of the study group according to the prosthetic needs. A total of $376(94.0 \%)$ did not have any prosthetic need. Only 14 (3.5\%) and 15 (3.75\%) subjects needed one unit prosthesis in the upper and lower jaws, respectively. The need for full prosthesis was seen only among $2(0.50 \%)$ subjects and the findings were statistically highly significant $(\mathrm{p}<0.001)$. Among those who required oneunit prosthesis, the need was predominantly seen in the 35-44 years onwards (Table VIII).

Table IV. Loss of Attachment (LOA) scores in the study group.

\begin{tabular}{|c|c|c|c|c|c|c|}
\hline Gender & $\begin{array}{c}\text { 0-3 mm No. } \\
(\%)\end{array}$ & $\begin{array}{c}\text { 4-5 mm No. } \\
(\%)\end{array}$ & $\begin{array}{c}\text { 6-8 } \mathrm{mm} \text { No. } \\
(\%)\end{array}$ & $\begin{array}{c}\text { 9-11 mm No. } \\
(\%)\end{array}$ & $\begin{array}{c}\text { Total No. } \\
(\%)\end{array}$ & $\begin{array}{l}\text { Statistical } \\
\text { Inference }\end{array}$ \\
\hline Male & $123(41.28)$ & $26(49.06)$ & $16(48.48)$ & $12(75.00)$ & $177(44.25)$ & \multirow{3}{*}{$\begin{array}{c}\text { Chi square }\left(\chi^{2}\right)=7.938 \\
\text { P value }=0.04 * *\end{array}$} \\
\hline Female & $175(58.72)$ & $27(50.94)$ & $17(51.52)$ & $4(25.00)$ & $223(55.75)$ & \\
\hline Total & $298(74.50)$ & $53(13.25)$ & 33 (8.25) & $16(4.00)$ & $400(100)$ & \\
\hline
\end{tabular}

Table V. Decayed, Missing, Filled Teeth (DMFT) Index scores in the study group.

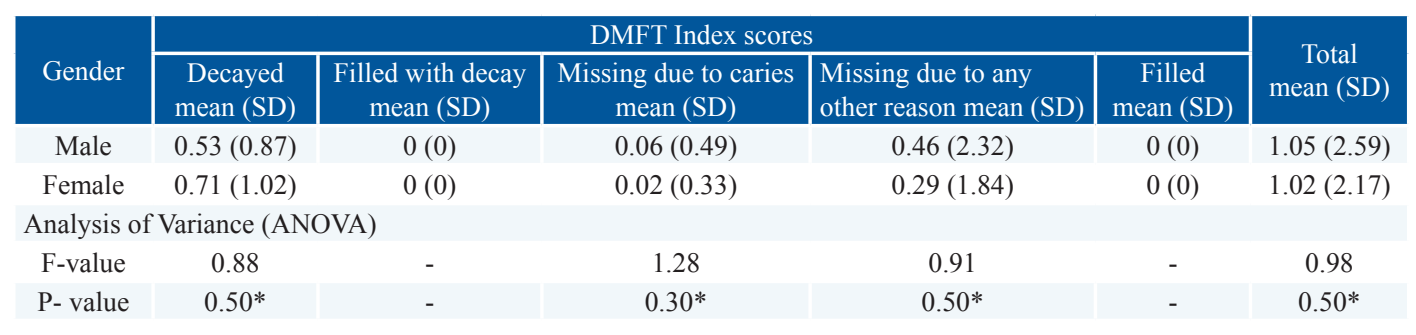

*NS=Not Significant

Table VI. Age-wise distribution of mean dmft/DMFT Index scores.

\begin{tabular}{|c|c|c|c|c|c|c|}
\hline \multirow[b]{2}{*}{$\begin{array}{c}\text { Age group } \\
\text { (in years) }\end{array}$} & \multicolumn{5}{|c|}{ DMFT Index scores } & \multirow{2}{*}{$\begin{array}{c}\text { Total } \\
\text { mean }(\mathrm{SD})\end{array}$} \\
\hline & $\begin{array}{l}\text { Decayed } \\
\text { mean (SD) }\end{array}$ & $\begin{array}{l}\text { Filled with decay } \\
\text { mean (SD) }\end{array}$ & $\begin{array}{l}\text { Missing due to caries } \\
\text { mean (SD) }\end{array}$ & $\begin{array}{l}\text { Missing due to any other reason } \\
\text { mean (SD) }\end{array}$ & $\begin{array}{c}\text { Filled } \\
\text { mean }(\mathrm{SD})\end{array}$ & \\
\hline $2-5$ & $0.68(0.86)$ & $0(0)$ & $0.13(0.79)$ & $0.33(1.64)$ & $0(0)$ & $1.12(2.27)$ \\
\hline $6-12$ & $0.78(1.13)$ & $0(0)$ & $0(0)$ & $0.53(1.86)$ & $0(0)$ & $1.31(2.40)$ \\
\hline $13-15$ & $0.56(0.70)$ & $0(0)$ & $0(0)$ & $0.48(1.60)$ & $0(0)$ & $1.03(1.60)$ \\
\hline $16-34$ & $0.51(0.86)$ & $0(0)$ & $0.03(0.29)$ & $0.33(2.33)$ & $0(0)$ & $0.86(2.45)$ \\
\hline $35-44$ & $0.47(0.78)$ & $0(0)$ & $0.09(0.66)$ & $0.17(0.93)$ & $0(0)$ & $0.72(1.45)$ \\
\hline $45-64$ & $0.89(1.18)$ & $0(0)$ & $0.04(0.35)$ & $0.14(1.18)$ & $0(0)$ & $1.07(1.89)$ \\
\hline $65-74$ & $0.38(0.85)$ & $0(0)$ & $0(0)$ & $1.31(4.72)$ & $0(0)$ & $1.69(4.76)$ \\
\hline \multicolumn{7}{|c|}{ Analysis of Variance (ANOVA) } \\
\hline F-value & 1.01 & - & 0.65 & 0.79 & - & 0.86 \\
\hline $\mathrm{P}$ - value & $0.40^{*}$ & - & $0.50 *$ & $0.60^{*}$ & - & $0.60 *$ \\
\hline
\end{tabular}

*NS=Not Significant

Table VII. Prosthetic needs of the study group.

\begin{tabular}{|c|c|c|c|c|c|c|c|c|}
\hline \multirow{3}{*}{ Gender } & \multicolumn{8}{|c|}{$\begin{aligned} \text { Prosthetic Needs } \\
\end{aligned}$} \\
\hline & \multicolumn{2}{|c|}{ Prosthesis not required } & \multicolumn{2}{|c|}{ Need for one unit prosthesis } & \multicolumn{2}{|c|}{ Need for a combination } & \multicolumn{2}{|c|}{ Need for full prosthesis } \\
\hline & $\begin{array}{l}\text { Maxillary } \\
\text { No. }(\%)\end{array}$ & $\begin{array}{l}\text { Mandibular } \\
\text { No. }(\%)\end{array}$ & $\begin{array}{l}\text { Maxillary } \\
\text { No. (\%) }\end{array}$ & $\begin{array}{l}\text { Mandibular } \\
\text { No. }(\%)\end{array}$ & $\begin{array}{l}\text { Maxillary } \\
\text { No. }(\%)\end{array}$ & $\begin{array}{l}\text { Mandibular } \\
\text { No. (\%) }\end{array}$ & $\begin{array}{l}\text { Maxillary } \\
\text { No. (\%) }\end{array}$ & $\begin{array}{l}\text { Mandibular } \\
\text { No. (\%) }\end{array}$ \\
\hline Male & $161(42.82)$ & $172(45.14)$ & $11(78.57)$ & $3(20.00)$ & $3(37.50)$ & $0(0)$ & $2(100)$ & $2(100)$ \\
\hline Female & $215(57.18)$ & $209(54.86)$ & $3(21.43)$ & $12(80.00)$ & $5(62.50)$ & $2(100)$ & $0(0)$ & $0(0)$ \\
\hline Total (400) & $376(94)$ & $381(95.25)$ & $14(3.5)$ & $15(3.75)$ & $8(2.00)$ & $2(0.50)$ & $2(0.50)$ & $2(0.50)$ \\
\hline $\begin{array}{l}\text { Statistical } \\
\text { Inference }\end{array}$ & & $\begin{array}{r}\text { Me } \\
\text { Chi square } \\
\text { P value }\end{array}$ & $\begin{array}{l}=409.83 \\
000 * * *\end{array}$ & & & $\begin{array}{r}\text { Man } \\
\text { Chi square } \\
\text { P value }<\end{array}$ & $\begin{array}{l}\text { ole } \\
=405.07 \\
000 * * *\end{array}$ & \\
\hline
\end{tabular}

***HS=Highly Significant 
Table VIII. Age-wise distribution of prosthetic needs.

\begin{tabular}{|c|c|c|c|c|c|c|c|c|}
\hline \multirow{3}{*}{$\begin{array}{l}\text { Age group } \\
\text { (in years) }\end{array}$} & \multicolumn{8}{|c|}{ Prosthetic Needs } \\
\hline & \multicolumn{2}{|c|}{ Prosthesis not required } & \multicolumn{2}{|c|}{ Need for one unit prosthesis } & \multicolumn{2}{|c|}{ Need for a combination } & \multicolumn{2}{|c|}{ Need for full prosthesis } \\
\hline & $\begin{array}{l}\text { Maxillary } \\
\text { No. }(\%)\end{array}$ & $\begin{array}{c}\text { Mandibular } \\
\text { No. }(\%)\end{array}$ & $\begin{array}{l}\text { Maxillary } \\
\text { No. }(\%)\end{array}$ & $\begin{array}{c}\text { Mandibular } \\
\text { No. }(\%)\end{array}$ & $\begin{array}{l}\text { Maxillary } \\
\text { No. }(\%)\end{array}$ & \begin{tabular}{|c|} 
Mandibular \\
No. $(\%)$
\end{tabular} & $\begin{array}{l}\text { Maxillary } \\
\text { No. (\%) }\end{array}$ & \begin{tabular}{|c|} 
Mandibular \\
No. (\%)
\end{tabular} \\
\hline $2-5$ & $45(11.97)$ & $45(11.81)$ & $0(0)$ & $0(0)$ & $0(0)$ & $0(0)$ & $0(0)$ & $0(0)$ \\
\hline $6-12$ & $57(15.16)$ & $59(15.48)$ & $2(14.28)$ & $0(0)$ & $0(0)$ & $0(0)$ & $0(0)$ & $0(0)$ \\
\hline $13-15$ & $27(7.18)$ & $27(7.09)$ & $0(0)$ & $0(0)$ & $0(0)$ & $0(0)$ & $0(0)$ & $0(0)$ \\
\hline $16-34$ & $109(28.99)$ & $106(27.82)$ & $0(0)$ & $3(20.00)$ & $0(0)$ & $0(0)$ & $0(0)$ & $0(0)$ \\
\hline $35-44$ & $59(15.69)$ & $56(14.70)$ & $2(14.28)$ & $4(26.67)$ & $0(0)$ & $1(50.00)$ & $0(0)$ & $0(0)$ \\
\hline $45-64$ & $62(16.49)$ & $68(17.85)$ & $6(42.87)$ & $2(13.33)$ & $2(25.00)$ & $0(0)$ & $2(100)$ & $2(100)$ \\
\hline $65-74$ & $17(4.52)$ & $20(5.25)$ & $4(28.57)$ & $6(40.00)$ & $6(75.00)$ & $1(50.00)$ & $0(0)$ & $0(0)$ \\
\hline Grand Total (400) & $376(94)$ & $381(95.25)$ & $14(3.5)$ & $15(3.75)$ & $8(2.00)$ & $2(0.50)$ & $2(0.50)$ & $2(0.50)$ \\
\hline $\begin{array}{l}\text { Statistical } \\
\text { Inference }\end{array}$ & & $\begin{array}{r}\mathrm{Ma} \\
\text { Chi square } \\
\text { P value }\end{array}$ & $\begin{array}{l}\text { xilla } \\
\chi 2)=102.01 \\
0.000 * * *\end{array}$ & & & $\begin{array}{r}\text { Ma } \\
\text { Chi square } \\
\text { P value }\end{array}$ & $\begin{array}{l}(\chi 2)=66.29 \\
0.000^{* * *}\end{array}$ & \\
\hline
\end{tabular}

***HS=Highly Significant

\section{Discussion}

The primitive tribes in India have distinct health problems, mainly governed by multi-dimensional factors such as habitat, difficult terrains, varied ecological niches, illiteracy, poverty, isolation, superstitions and deforestation. The tribal people in India have their own life styles, food habits, beliefs, traditions and socio-cultural activities.

The health and nutritional problems of the vast tribal populations are varied because of the bewildering diversity in their socio-economic, ethnological, cultural and ecological settings. They are often characterized by their own language, heritage, love for freedom and selfidentity and this holds true for the Birhors too. A systematic review of the studies pertaining to the tribal population is scarce and no comprehensive data is available and this study would add to the existing knowledge about these native people.

The present study was carried out on Birhors residing in Mandu Block of Ramgarh District, Jharkhand. The sample size was 400 subjects divided into five age groups: $2-5,6-12,13-15,35-44$ and $65-74$ years. The present study evidently showed that a majority $(84.25 \%)$ of the Birhors routinely used the locally available twigs of Sakhua trees to clean their teeth. The Sal tree is known for its resinous exudates known as Sal dammar or Indian dammar and is popularly used as an astringent in local medicine since primeval time. The results of the present study were in agreement with the studies conducted by Naheeda et.al. [9] among Konda Reddy tribes (93.60\%) and Kadanakuppe $\mathrm{S} \&$ Bhat PK [10] among Iruligas who used chew sticks $(79.8 \%)$. However, this was in disagreement with the study findings of Raju PK et.al. [11] where only 31.1\% tribal children used twigs and in the study by Vijayakumar $\mathrm{N}$ et.al. [12] where only 10\% Sugali tribes used neem sticks.

Only $8.75 \%$ Birhors used a tooth brush to clean their teeth and this was similar to the findings of Bhowate RR et al. [13] where a lower use of the toothpaste and tooth brush was seen in comparison to other materials used for cleaning the teeth. It was interesting to note that all the Kandha tribals used datun twigs to clean their teeth as reported by Vaish RP et.al. [14] as also in the study by Naheeda et.al. [9] where none of the tribals used the tooth brush.

A majority of the Birhors (95.25\%) were healthy and did not present with oral mucosal lesions and was in agreement with the findings of Ikeda $\mathrm{N}$ et.al. [15] where only $4.9 \%$ Cambodian subjects had such lesions. Leukoplakia was found in 3\% subjects and this was in disagreement with that reported $(0.12 \%)$ by Kadanakuppe S \&Bhat PK [10] and Vijayakumar N et.al. [12] where a whopping 18.9\% Sugali tribals had leukoplakia.

The present study showed that a majority of the Birhors (95.25\%) were periodontally quite healthy. This finding was comparable to the findings of the study carried out by Dey SM et.al. [16] where 14.8\% Koraga tribals had healthy gums. However, this was in contrast to that reported by Philip B et.al. [17] where $73.6 \%$ tribals in Nilgiris had periodontal disease and Valsan I et.al. [18] on Paniya tribes, where $76.9 \%$ subjects had periodontal disease. Bleeding gums was most commonly seen in all the age groups and predominantly seen in the $13-15$ year age group $(3.44 \pm 2.77)$ and was in disagreement with the findings of the study by Kumar G et.al. [19] where it was predominantly seen in the 35 -44 year age group $(0.91 \pm 0.08)$.

The presence of mean shallow and deep pockets for the group was $0.62 \pm 0.93$ and $0.15 \pm 0.43$ and this was in agreement with the findings of Naheeda et.al. [9] where they were $0.91 \pm 0.91$ and $0.02 \pm 0.15$, respectively. The mean number of sextants affected by bleeding gums and calculus were $2.65 \pm 2.31$ and $1.07 \pm 1.68$ sextants, respectively. This was in disagreement with that reported by Bhat PK \&Kadanakuppe S [20] where they were $0.38 \pm 1.11$ and $3.87 \pm 2.44$ sextants, respectively. Deep pockets were seen across the age groups 16-34 and above (0.14) and this was in contrast to that reported by Kumar G et.al. [19] where 
they were seen only in the age groups of 35-44 year (0.84) and 65-74 years (0.65) and by Kumar V et.al. [21] and Spalj S \& Plancak D [22] in their study on subjects aged 15 years and older where they found that the mean number of healthy sextants varied from 3-5 and the mean number of sextants with bleeding gums or dental calculus varied from 1-3. These findings were in accordance with the findings of the present study.

Schamschula et al. [23] in their study observed that the mean scores for periodontal involvement increased from 1.7 sextants at 20 years to 4.8 sextants at 43 years and over. However, these findings were not in accordance with the findings of the present study. It is interesting to note that the Birhors' periodontal status was quite healthy and this might in part be due to their usage of the Sakhua twigs in their daily oral hygiene routine. However, almost $45 \%$ natives have habituated themselves to tobacco. The Khaini that they use is crushed with the teeth to release its flavor and nicotine and unwanted juices are then expectorated (spat). This habit has been widespread among the dreary laborers who find the chewing habit a solace in their daily grind and continue to revolve it in their mouths upon returning to their homes. It would be felicitous to provide health education and efforts ought to be directed towards quitting of the harmful habits of alcohol consumption, smoking and the use of smokeless tobacco among the Birhors.

In the current study dental caries prevalence was quite low. The mean decayed, missing, and filled tooth (dmft) score was $1.12 \pm 2.27$ in subjects $2-5$ years old and in the higher age groups of 35-44 years \& 65-74 years, the scores were $0.72 \pm 1.45$ and $1.69 \pm 4.76$ teeth, respectively. This was not in accordance with the findings of Kumar et al. [19] where the prevalence was $3.56 \pm 1.93$ and $5.21 \pm 2.34$ and $7.42 \pm 4.29$ teeth, respectively, as also in the studies by Maurya et al.[24], Lang et al.[25] and Jayashantha and Johnson [26], where the mean DMFT scores were quite high.

Schamschula et al. [23] showed that the prevalence of dental caries increased from 17.1 teeth at 20 years to 20.7 teeth at 35 years. However, these finding were not in conformity with the findings of the present study. It might be conjectured that the higher levels of dental caries prevalence observed might be due to the ill effects of lifestyle and increased access to cariogenic foods and beverages among these tribes.

Naidu et al. [27] conducted a study of children aged $6-8,12$ and 15 years and found that $77 \%$ children had a need for some form of treatment and the most frequently occurring need was for dental fillings. These findings were similar to the findings of the present study. This might be due to the cost constraints and remoteness of the service providers in the tribal clusters.

The main limitation of this study is that it is crosssectional in nature and the findings cannot be extrapolated to the other Development Blocks in the District, due to the vast differences in the socio-demographic factors.
However, this limitation can be overcome by a larger sample size drawn from across the District and undertaking studies of a longitudinal nature. The results of this study could form a base-line data for the health administrators for planning suitable programmes for the betterment of oral health among the tribals in the District of Ramgarh, as well as across the State of Jharkhand.

\section{Conclusion}

The present study was carried out to assess the oral health status and treatment needs of Birhor tribals residing in Ramgarh District, Jharkhand. A preponderance of Birhors used Sakhua twigs to clean their teeth. Almost half of the study subjects were habituated to the scourge of tobacco usage. Nearly all (95\%) subjects were outright healthy and had no oral mucosal lesions. The mean decayed, missing, and filled teeth (DMFT) Index scores among males and females were $1.05 \pm 2.59$ and $1.02 \pm 2.17$, respectively. Among the males, $0.44 \pm 2.60$ subjects needed one/two surface fillings. A majority (94.0\%) of the Birhors did not have any prosthetic need. A greater part of the Birhors $(95.25 \%)$ were periodontally healthy to a fairly large extant. It is mooted that a State-wide survey would be essential to obtain a realistic picture of the oral health status and treatment needs of the Birhors in Jharkhand.

\section{Acknowledgements}

The authors would like to thank the District Administration for providing details of the tribal clusters and all the Birhor participants who enabled this study. Immense thanks are also due to Dr. Sunil Kumar Singh, Civil Surgeon, Dr. Ashok Ram, Medical Officer-In-charge, Dr. Syed Hedayetullah, Medical Officer, Mr. Ramasheesh Pandit, Family Planning Worker, who are doing yeomen service at the Community Health centre, Mandu, Ramgarh District, Govt. of Jharkhand, India. A special note of thanks goes to Mrs. Leela Lagoon and all her gentle nursing staff who diligently participated in the survey.

\section{References}

1. Balgir RS. Tribal Health Problems, Disease Burden and Ameliorative Challenges in Tribal Communities with Special Emphasis on Tribes of Orissa. Proceedings of National Symposium on "Tribal Health" 19th-20th October 2006, Regional Medical Research Centre for Tribals (ICMR), Jabalpur. 2007, pp 161-176.

2. Sahani R, Nandy SK. Particularly Vulnerable Tribal Groups in India: An Overview. J Anthropol Survey India. 2013;62:851-65.

3. Halder S. Level of Wellbeing of Tribal Population of Churchu Block, Hazaribagh, Jharkhand. IOSR-JHSS.2015;20:28-35.

4. The Birhors - a little known tribe of Jharkhand. Available from: http://jainsagar.com/the-convivial/the-birhors-a-little-know-tribeof-jharkhand/

5. Scheduled Tribe (ST) Data - Census 2011 India. Available from: https://www.census2011.co.in/

6. Palliyal S. Oral Health Disparities among the Privileged and the 
Underprivileged Tribes of India - A Study on Periodontal Disease Prevalence. Int J Epidemiol 2015;44 (Suppl): i31

7. Kothari CR. Research Methodology - Methods and Techniques. In: Chapter 8- Sampling fundamentals. New Age International Publishers P Ltd. 2nd Edition, New Delhi, 2004; pp 152-183.

8. American Dental Association. A dental health program for schools. Chicago (IL): The American Dental Association; 1954: 16. 9. Naheeda, Asif SM, Padma M, Paul A. Assessment of Periodontal Status of Konda Reddy Tribe in Bhadrachalam, Khammam District, India. J Clin Diagn Res. 2015;9:ZC23-ZC25. 10. Kadanakuppe S, Bhat PK. Oral health status and treatment needs of Iruligas at Ramanagara District, Karnataka, India. West Indian Med J. 2013;62:73-80.

11.Raju PK, Vasanti D, Kumar JR, Niranjani K, Kumar MS. Oral Hygiene Levels in Children of Tribal Population of Eastern Ghats: An Epidemiological Study. J Int Oral Health. 2015;7:108-110.

12. Vijayakumar N, Rohini C, Reddy C, Sunkari M, Kumar MS, Malar CI. Assessment of Oral Health Status and Treatment Needs among Sugali Tribes in Telangana Region: A Cross-Sectional Study. Int J Oral Health Med Res. 2017;3:21-26.

13. Bhowate RR, Borle SR, Chinchkhede DH, Gondhalekar RV. Dental health amongst 11-15-year-old children in Sevagram, Maharashtra. Indian J Dent Res. 1994;5:65-68.

14. Vaish RP. Prevalence of caries among school-going tribal children in Ganjam district, Orissa. J Indian Dent Assoc. 1982;54:375-377.

15. Ikeda N, Handa Y, Khim SP, Durward C, Axéll T, Mizuno $\mathrm{T}$ et al. Prevalence study of oral mucosal lesions in a selected Cambodian population. Community Dent Oral Epidemiol. 1995;23: 49-54.

16. Dey SM, Nagarathna DV, Mathews Jude. Assessment of periodontal health status among Koraga tribes residing in Mangalore taluk: a cross sectional study. Int J Res Med Sci. 2017;5:3980-3984.

17. Philip B, Chithresan K, Vijayaragavan VS, Maradi A.
Prevalence of Periodontal diseases among the adult tribal population in Nilgiris - an epidemiological study. Int J Pub Health Dent. 2013;4:8-12.

18. Valsan I, Joseph J, Janakiram C, Mohamed S. Oral Health Status and Treatment Needs of Paniya Tribes in Kerala. J Clin Diagn Res. 2016;10:ZC12-ZC15.

19. Kumar G, Tripathi RM, Dileep CL, Trehan M, Malhotra S, Singh P. Assessment of oral health status and treatment needs of Santhal tribes of Dhanbad District, Jharkhand. J Int Soc Prev Community Dent. 2016;6:338-343.

20. Bhat PK, Kadanakuppe S. Periodontal health status and oral hygiene practices of Iruliga tribal community residing at Ramanagar district, Karnataka, India. J. Int Oral Health 2010;2:17-26.

21. Kumar V, Agarwal V, Khatri M, Singh G, Sunny. Prevalence of periodontitis in rural and urban population. Indian J Comm Health. 2015;27:366-371.

22. Spalj S, Plancak D. Comparison of periodontal health of two different rural population types in Croatia. Acta Stomatol Croat. 2000;34:183-187.

23. Schamschula RG, Cooper MH, Wright MC, Agus HM, Un PS. Oral health of adolescent and adult Australian aborigines. Community Dent Oral Epidemiol. 1980;8:370-374.

24. Maurya R, Kundu D, Singh H, Mishra H. Oral health status, dental caries experience and treatment needs of population of Jammu city. Int J Oral Health Dent. 2015;1:164-167.

25. Lang WP, Hamard MA, Mackenzie RC. Rural dental program in Haiti. Community Dent Oral Epidemiol. 1984;12:233-236.

26. Jayashantha P, Johnson NW. Oral Health Status of the VeddasSri Lankan Indigenous People. J Health Care Poor Underserved. 2016;27:139-147.

27. Naidu R, Prevatt I, Simeon D. The oral health and treatment needs of schoolchildren in Trinidad and Tobago: findings of a national survey. Int J Paediatr Dent. 2006;16:412-418. 